\title{
FINANCIAL ROLES AND ITS EFFECT ON PERSISTENCE OF FEMALE STUDENTS IN DISTANCE EDUCATION PROGRAMS IN GHANA
}

\author{
Dr. Beatrice Asante SOMUAH \\ College of Distance Education \\ University of Cape Coast \\ Cape Coast, Ghana \\ Dr. Florence Muthoni ITEGI \\ Department of Educational Management, Policy and Curriculum Studies \\ Kenyatta University \\ Nairobi, Kenya \\ Dr. Samson Ikinya KARIUKI \\ Department of Educational Management, Policy and Curriculum Studies \\ Kenyatta University \\ Nairobi, Kenya
}

\begin{abstract}
In recent times when there has been a shift in public benefit of education from the higher education to basic education, beneficiaries of higher education take responsibilities of most of their financial commitments as students. The focus of the study was to find out the extent to which financial responsibilities affect the persistence of female students accessing higher education through the distance education programs. A correlational research design was used to describe and predict the effect of financial responsibilities on persistence of 441 female students drawn from selected public universities in Ghana. Data was collected using questionnaires and analyzed with descriptives and simple linear regression. It was found that financial roles had positive effect on persistence of the female students. The study recommended that female students were exposed to the sources of funding to enable them mitigate the effect financial roles might have on their persistence and academic progression.
\end{abstract}

Keywords: Financial roles, distance education, persistence, academic progression, female students.

\section{INTRODUCTION}

The interplay of economic and cultural factors may have the potential in determining the level of students' persistence in a college (Burrus et al., 2013). In support, Goldrick-Rab (2016) also asserted that a student's financial responsibilities can be one of the important predictors of persistence towards degree attainment as these directly affect the provision of resources at home and indirectly affect supply of the needed social investments necessary to succeed in college. In the view of Nordenmark (2004), one's control over financial responsibilities can create a feeling of contentment as they provide an individual with a greater meaning to life and more control over other equally important life situations. In concurring to this assertion, findings from a study conducted by Bynum (2016) showed a 
positive relationship between financial status and persistence among female college students. Carney-Crompton and Tan (2002) added that some variables that determine the persistence of both male and female students include household income, the number of dependents, and the financial aid received by the student. The current study looked at financial responsibilities in terms of number of dependents, ability to pay fees and accessibility to financial support in an attempt to examine how female students feel the blunt if decisions have to be made in relation to how to continue with schooling through the distance education mode in Ghana.

\section{PURPOSE OF THE STUDY}

This study investigated the effect of financial roles on persistence of female students in distance education programs in Ghana. This was deemed necessary due to the background characteristics of the female students who accessed higher education by distance learning as being self-dependent and also the fact that economic factor may a have direct relationship with the persistence of students on distance education programs. It was also the belief that the finding of the study might be beneficial to the female student and to the administrators of institutions of distance education. The study was guided by a null hypothesis as stated below;

$>$ Ho1: Financial responsibilities are not statistically significant predictor of persistence of female students in distance education programs in Ghana.

\section{LITERATURE REVIEW}

Student attrition theory by Bean and Metzner's (1985) was used to support the study. This theory was developed in relation to organizational turnover and attitude-behavior interactions theories (Al-Dossary, 2008). Bean and Metzner (1985) stressed that student decisions to leave colleges were related to peoples' decisions to leave their places of work. Bean and Metzner (1985) claimed that the student persistence/retention theories developed by Spady, Tinto and Pascarella were very much skewed on socialization of students in institutions and did not take into consideration the external factors which were likely to affect non-traditional students. This is due to the fact these non-traditional students had fewer chances of experiencing social integration opportunities provided by institutions as seen among students who patronize distance education institutions. Most of these students are non-residents and do not benefit much from most of the efforts made by colleges for socially integrating students into the academic environment (Bean \& Metzner, 1985). Bean and Metzner (1985) therefore found that environmental variables were more important for non-traditional students than academic variables.

According to Bean and Metzner (1985), the four sets of variables that influenced student persistence student's grade point average, intention of the student to leave, background and defining variables of students and environmental variables such as finances, hours of employment, family responsibilities and opportunity to transfer. The authors opined that all these variables are external to institutions but have a direct effect on dropout decisions of non- traditional students like those accessing education through the distance education mode. They reiterated that when academic variables of non-traditional students were good but they faced poor environmental variables, they were likely to leave school (Bean \& Metzner, 1985). On the other hand, students were most likely to remain enrolled when environmental variables were excellent and academic variables were poor because low scores on the academic variables were usually compensated for by good environmental support (Bean \& Metzner, 1985). 
In a research involving 50 institutions in the United States, Westrick and Robbins (2012) found that the effect of financial responsibilities on persistence has a relationship with a student's first year Grade Point Average. This implied that financial responsibilities may have contributed immensely towards the academic performance and persistence of students in the study. A related study by Abdu-Raheem (2015) on financial background as a predictor of academic performance among secondary school students in Nigeria, Abdu-Raheem reported that there was relationship between parents' financial background and academic performance of the respondents. The study stressed the need for the formulation of good programs or policies aimed at creating an academic balance between students from rich and the poor backgrounds. Though Paulsen and St. John's (2002) comprehensive studies of financial responsibilities and higher education showed a relationship between financial responsibilities and persistence, the researchers indicated that there were several other significant interactional effects. For instance, the study reported that women from lowincome and single-parent families were less likely to persist than men because the attraction to leave school in order to seek employment opportunities was usually high (Paulsen \& St. John, 2002).

Reay (2003) also conducted a qualitative study in United Kingdom among 12 working-class women who were attending higher education and found that the women especially those with children, were held between the need to earn money, meet domestic responsibilities and wanting to study. Reay further indicated that the women's narratives showed evidence of risks and costs involved as they made effort to participate in higher education. The study reported a severe financial hardship experienced by single mothers who were managing paid work with studies (Reay, 2003). Such financial difficulties usually exposed single women with low financial background to the risk of dropping out of university particularly when they experience the extra cost incurred by educating their children (Reay, 2003). This implication is that single mothers who are female students are more likely to have problems with persistence as compared to their married counterparts.

Distance education in most institutions in Ghana offer a face-to-face option as a support service to students (Simpson, 2016). This however, creates an additional financial burden to these students as they need to commute to the designated study centers to access this facility. As noted by Goldrick-Rab (2010), distance education is a popular choice among lower income students and financial support is associated with the level of persistence of most of such students. Another study by Terriquez and Gurantz (2015) investigated how financial factors contribute to straining the upward educational mobility experienced by a cohort of young adults. Using telephone survey and in-depth interview, the researchers gathered data from 18 to 26 year olds to analyze their decisions for leaving college with intentions to return or patterns of stopping out (Terriquez \& Gurantz, 2015). It was found that financial considerations which played a key role in shaping the persistence decisions of the respondents included accessibility to a financial aid, attending to family financial obligations, ability to pay for housing expenses and rising tuition rates (Terriquez \& Gurantz, 2015).

A study by Mamiseishvili and Deggs (2013) also investigated how demographic characteristics, environmental factors and personal goals of low-income students affected their persistence to degree completion. The study aimed at examining persistence outcomes over a 3-year period across the national sample of students from low financial backgrounds at public institutions using a multinomial logistic regression analysis. The study revealed that different sets of factors predicted persistence and transfer for low-income students in the study. The researchers recommended that identifying these factors will help administrators to better serve the needs of their students (Mamiseishvili \& Deggs, 2013). As proposed by the researchers in the above study, having information on the characteristics of students 
who patronize an institution will go a long way to help administrators as they formulate policies and interventions to assist students. It was the aim of the current study to produce information on female students to serve as a basis for decision making among administrators in distance education institutions.

In relation to the foregoing, Adu-Yeboah (2011) conducted a study among mature female students in one public university in Ghana using a qualitative approach. The aim of the study was to explore the experiences of these mature female students and also find out the strategies they adopted to navigate through higher education as they juggle with other duties. The study revealed that the female students adopted personalized strategies to enable them to progress through their education. Adu-Yeboah (2011) concluded that the economic backgrounds, marital status and family lives were some of the major factors that influenced the way women students experience higher education in Ghana.

Contributing to the discussions above, Renehan (2015) had commented that attending college in the past decade has transformed from being an intellectual pursuit to a financially burdensome risk for most students and their families. It has, therefore, become very essential for students to have some form of financial aid or parental support in order to attend and complete college (Renehan, 2015). Highlighting on women in college, the American Association of University Women (AAUW, 2016) reported that many female students tend to access student loans than men and also take longer period in repaying these loans. Currently, over $\mathbf{4 0 \%}$ of women in American households are the primary breadwinners with children, with single mothers accounting for almost two thirds of this number (Finningan, 2015).

In most societies, women's major roles were narrowed to homemaking and child nurturing. This constrained their aspirations and accessibility to higher education and professional occupations so much so that when women started pursuing work, most employers thought they were seeking temporary jobs in order to supplement family income (Saleh, Yu, Leslie \& Seydel, 2017). With such belief, low salaries were offered to women compared to men who possessed the same level of education and doing the same job (Saleh, et al., 2017). For instance, Kitroeff and Rodkin (2015) revealed that women with MBA certificates earned an average of $\$ 35,000$ less than the men even after eight years of graduation and the women took a year longer in repaying their student loans. Additionally, Kitroeff and Rodkin (2015) found that student loans took $25 \%$ of women earnings compared to $14 \%$ of the men's earnings.

In the situation where the cost of attending higher education has increased close to $300 \%$ over past two decades, it becomes imperative that as one discusses persistence, a student's ability to pay for a university education must also be considered (Bean, 2005; Burrus et al., 2013). Such situations usually compel some students to seek loans and other financial aids in order to support themselves and care for their families as well. Saleh et al. (2017) however, found that one of the major concerns about "student loans is the ability to repay them, and this has been an issue of importance to all college students, especially to female students" (p. 228). The focus of this study therefore was to find out how the financial responsibilities of these female students affected their persistence as students in distance education programs.

\section{METHODOLOGY}

The correlational research design was used to predict the effect of financial roles on the persistence of female students. This design was deemed appropriate for the study as it allowed for the determination of the relationship as well as prediction to be made between 
the variables under study (Creswell 2014). It also allowed for the use of collecting, analyzing and presenting data quantitatively as used in this study (Creswell 2014). With the correlational research design, the relationships as well as the effect of financial roles on persistence of female students in distance education design would be established.

\section{Participants of the Study}

The participants of the study were selected from a target population of $\mathbf{7 8 4 9}$ female students pursuing education in two public universities in Ghana. Using the Yamane's formula for sample selection, a sample of $\mathbf{4 4 1}$ female students was selected from. The participants were then selected through a stratified random sampling from 21 study centers from two public universities in Ghana by the proportionate method. The study centers were selected using an inclusion criterion of having $\mathbf{9 0}$ and above female students. This criterion was necessary to enable the result obtained to be subjected to an inferential statistic.

\section{Data Collection and Analysis Procedures}

The questionnaire used for collecting data had two sections. The first part looked at the demographic data (age, marital status and number of dependents) while the second part dealt with the variables under study (financial roles and persistence). These were measured on a continuous nature. Then items for persistence were modified from Davidson, Hall and Milligan's (2009) College Persistence Questionnaire. Out the sample of 441, 377 of the questionnaire returned were valid for analysis of results. Responses were analyzed with the help of means, standard deviation and simple regression analysis using a five point Likert scale (1-strongly disagree to 5-strongly agree). The means of the responses were used to describe the extent to which the respondents agreed or otherwise with the statements under discussion. To facilitate data analysis, the means of the responses were interpreted as follows: 3.41 - 5.00 (Agree), 2.61 - 3.40 (Moderately Agree) and 1.00 - 2.60 (Disagree).

\section{FINDINGS AND DISCUSSIONS}

\section{Profile of Respondents}

The age ranges of the study participants were found to be as follows; those aged between 18-25 years were $155(41 \%) ; 25-35$ years were $193(51 \%)$; $36-45$ years were $22(6 \%)$ while participants aged above 46 were $7(2 \%)$. The age range with the highest number of participants was 25-35 (51\%). Participants of were found to fall within 3 main categories namely; single 235(62\%), married 138 (37) divorced and widowed 4(1). This implied that the majority of the female students were single. The study further sought to find out if the respondents had dependents they were supporting. It was revealed that $222(52 \%)$ of the respondents had children were supporting, 141(32\%) and $67(16 \%)$ cared for their parents and siblings respectively. Table 1 presents in the descriptive analysis of responses of the female students in relation to their financial responsibilities. 
Table 1. Financial Responsibilities as Viewed by Female Students

\begin{tabular}{lcc}
\hline Financial Responsibilities & Mean & SD \\
\hline Financial needs of children & 3.8 & 1.3 \\
Financial needs relatives. & 3.5 & 1.2 \\
Inability to meet academic needs. & 3.6 & 1.3 \\
Families pay fees. & 2.4 & 1.7 \\
Not responsible for paying fees. & 2.5 & 1.3 \\
\hline Access Students' Loan Fund. & 2.5 & 1.4 \\
\hline Support from employers. & 2.6 & 1.4 \\
\hline Loans from banks & 3.0 & 1.5 \\
\hline Engage in more than one job & 3.7 & 1.3 \\
\hline Average Score & 3.1 & 1.4 \\
\hline
\end{tabular}

As shown in Table 1, provision of the needs of children and relatives were highly scored with mean values of $3.8(S D=1.3)$ and $3.5(S D=1.2)$ respectively by the respondents. This meant that the needs of close relations were of priority to the female students despite the fact that they had some academic needs to attend to as well. This finding is in support of the study by Reay (2003) who found that females, especially those who had children, were held usually between the need to meet domestic responsibilities and desire to study. Sha'aban as cited in McClusky (2017) also opined that it was the role of families to cooperate when it comes to the maintenance of the economic welfare of the family as depicted among the female students in this study. As complemented by Riel (2011), individuals are most likely to lose personal honor and dignity if they do not provide the needs of the family.

It can also be observed from Table 1 that respondents agreed (Mean=3.6, SD=1.3) to the statement that they faced problems in trying to raise enough funds for their academic needs. This finding confirmed a survey conducted by the Higher Education Research Institute in 2002 in the United States which found that $65.3 \%$ of the freshmen have either "some concern" or "major concerns" about not having enough money to complete their college degrees (Nonis \& Hudson, 2006, p. 151). Despite this handicap, the respondents disagreed (Mean=2.9, SD=1.7) with the statement that their families supported them in paying for the cost of their academic bills.

The study went further to find out if the female students have access to Students Loan Fund or get financial support from their places of work. The results as seen from Table 1 show that the respondents were in disagreement (Mean=2.5, $S D=1.4)$ of this statement. The meaning was that respondents claimed that they did not receive any form of financial help from the Student Loan Fund. The picture as seen here is in line with the study conducted in Uganda by Jansson, Bukuluki, Hojer (2017) which found most female students regardless of their background were more dependent upon private or self-sponsorship in paying for their academic bills in higher institutions as compared with male students who accessed public sponsorship to a greater degree. Terriquez and Gurantz (2015) noted in their study among young adults that accessibility to financial aid played a key role in shaping the persistence decisions of the respondents. The results as displayed in Table 1 showed that most of the 
respondents claimed that they did not get any financial support from the families, Students Loan Fund or their employers. So the question was how were they able to meet their financial needs as students on distance education program? This question was reliably answered when the respondents agreed (Mean=3.7, SD=1.3) that they engaged in other businesses and jobs to raise some income to support themselves. This confirms the findings by Adu-Yeboah (2011) which found that most female students adopt personalized strategies to help them progress successfully through their education.

In addition to the above descriptive analysis, the study also tried to determine the extent to which financial responsibilities affect the persistence of female student in distance education program. In attempt to respond to this, a null hypothesis was derived as indicated below:

$>$ Ho1: Financial responsibilities are not a statistically significant predictor of persistence of female students in distance education programs in Ghana.

The scores on financial responsibilities and persistence were both computed individually and a continuous score was obtained for each of the variables and used to conduct a significance testing between the variables. The simple linear regression analysis was applied to test the effect of female students' financial responsibilities on their persistence in distance education programs. The variant of the independent variable was placed in the model to determine the coefficient of determination $\left(R^{2}\right)$ and used to explain the amount of variability explained in the dependent variable (persistence) by the independent variable (financial responsibilities). The effect size was also determined using the $R^{2}$. The $R$ indicated the relationship between the independent and the dependent variable, while the results from the ANOVA further established the strength of the significance of the relationship between the variables understudy. The results as obtained from the simple linear regression are presented in Table 2.

Table 2. Simple Regression Analysis of Financial Responsibilities and Persistence of Female Students

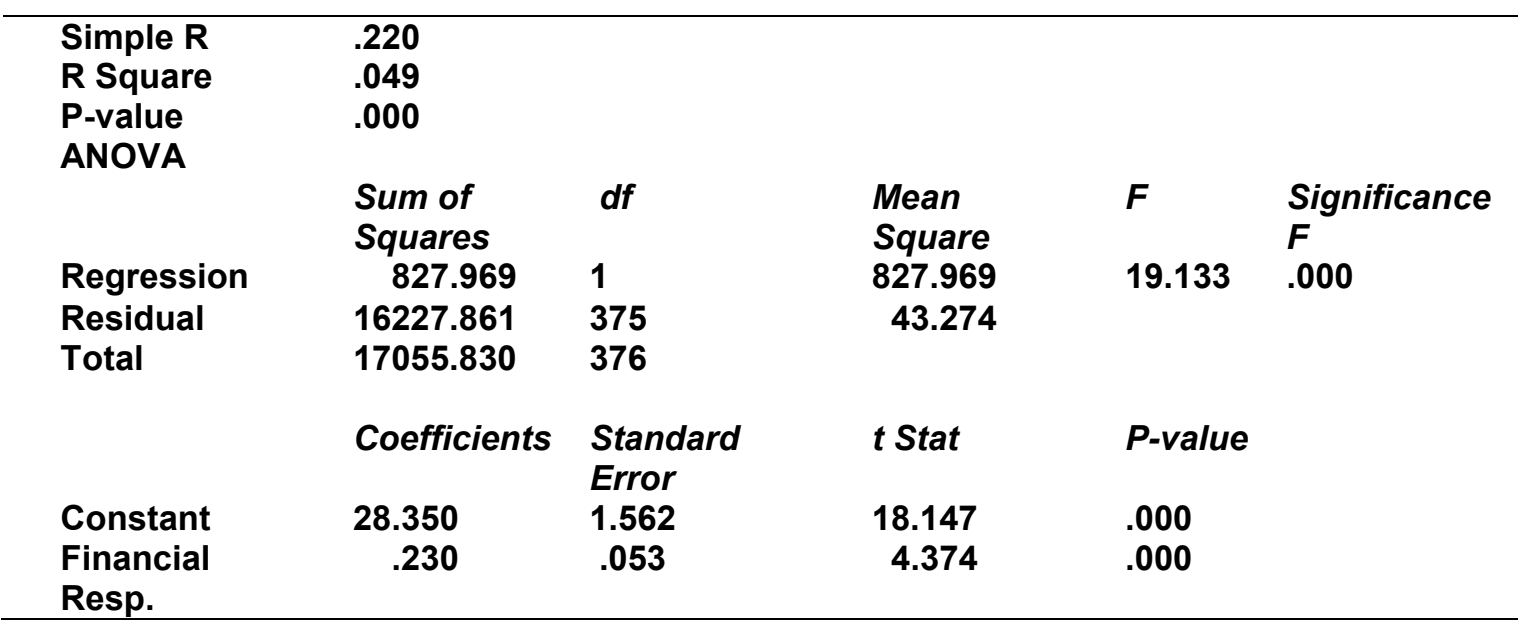

NOTE: $p<.001$

Table 2 depicts the results of the simple regression of financial responsibilities as a predictor variable and persistence as the dependent variable. It can be observed from Table 2 that, $R$ at .220 with a p-value of .001, implied there was a weak positive correlation or relationship between the predictor variable and the dependent variable. This result indicates that as financial responsibilities of female students increased their level of persistence also increased as well. The $R$-Square $\left(R^{2}\right)$ as portrayed in Table 2 indicated the proportion of the 
variance in the dependent variable which can be explained or predicted by the independent variable. As clearly seen in Table 2 , the value for $R$-Square $\left(R^{2}\right)$ was .049 . This implied that financial responsibilities explained close to $5 \%$ variance in persistence (multiplying .049 by 100). It also meant that about $95 \%$ of the variance not explained can be as a result of other factors. The $R$-Square $\left(R^{2}\right)$ also showed the effect size of .049. Applying Cohen's (1994) standard on interpretation of effect size where, $r=.10$ (small effect), $r=.30$ (medium effect) and $r=.50$ (large effect), an effect size of .049 is an indication that financial responsibilities had a small but significant effect on persistence of female students on distance education programs.

To further confirm how significant the relationship between financial responsibilities and persistence can be used to predict an outcome, a report on the analysis of variance (ANOVA) showing the sums of squares, the degree of freedom associated with each sum and the $F$ ratio are reported in Table 1.2. As it can be noted, the $f(1,376)=19.133$ which was significant at $p<.001$, meant that the regression model can be used to significantly predict the extent to which financial responsibilities affected persistence. In other words, at an effect size of .049, financial responsibilities was a predictor of the level of persistence among female students on distance education programs. Based on this result, the null hypothesis which indicated that financial responsibilities are not statistically significant predictor of persistence of female students in distance education programs in Ghana was rejected. It was therefore concluded that financial responsibilities can positively determine the persistence of female students.

The study went further to find out the model parameters (beta values) and the significance of these values to the regression model by looking at the coefficients of the predictor and the outcome variables using regression equation, $Y=a+\beta x_{1}+\varepsilon$, where $Y$ is the predicted value of Persistence, $a=$ the predicted value of Persistence if $x_{1}$ is zero, $\beta=$ effect in Persistence due to a unit of change in $x_{1}, x_{1}=$ independent variable (financial responsibilities) and $\varepsilon=$ other factors that influence Persistence but not observed. From Table 1.2, one can notice that the "Constant", which implied that the predicted value of persistence if financial responsibilities is zero is $\mathbf{2 8 . 3 5 0}$. The regression weight (Beta) that indicates the amount of change in the outcome (persistence) associated with a unit change in the predictor (financial responsibilities) is $\mathbf{. 2 3 0}$. With the guarantee that the model has some ability to predict persistence of female students, the regression model was refined by replacing the beta values with the coefficients in the regression equation seen as below:

$>$ Persistence $=a+\beta$ (financial responsibilities). Substituting the coefficient the equation is seen as Persistence $=28.350+.230$. Then multiplying the equation a unit of financial responsibilities to the results as: Persistence $=28.350+.230(1)$, and therefore Persistence $=\mathbf{2 8 . 5 8 0}$.

This meant at .230 ( $\beta=.230)$, a unit (1) increase in financial responsibilities, persistence was expected to yield a persistence of 28.580 . With p-value of .001 , it can be mentioned that there was a statistical significant effect of financial responsibilities on persistence of female students.

The foregoing results implied that an increase in the financial responsibilities of the female students would increase their level of persistence as seen in the regression model. In a reverse manner, a decrease in the financial responsibilities of the female students may lead to a decrease in their agility to be persistent on the course of study. The findings as established is in line with the study by Paulsen and St. John's (2002) which found that there was an association between financial responsibilities and persistence in higher education, but as revealed in this current study, Paulsen and St. John also had indicated the presence of 
several other significant interactional factors. Again, comments by Goldrick-Rab (2016) had indicated that though students may experience financial roles differently, financial concerns can exert serious impact on students' access to college and persistence towards attainment of degrees. As it can be noted in this study, participants had confirmed they experienced some financial difficulties but in contrast with the assertion made by Goldrick-Rab (2016), they seem determined to go against the odds to persist on their program.

The finding from the simple regression analysis also supports the study by Nielson (2015) which found that the women perceived their persistence in higher education in terms of jobseeking opportunity and channel for self-development. As reiterated by Nielson (2015), majority of the participants confirmed that their persistence was based on the belief that attaining a higher degree would help to break down structural barriers towards getting better jobs as most of the participants were in low-wage jobs and insecure occupations. This assertion was confirmed by the results of this study. The finding on financial responsibilities seemed to disagree with assertion made by Khattak (2013) that most women who participated and succeeded in higher education were from the elite and the upper middle classes who financially advantaged. The results from this study indicated that the respondents had financial difficulties but they showed the urge to succeed on their study against the odds.

\section{CONCLUSIONS AND RECOMMENDATIONS}

It can be concluded that though other factors may play a role in determining the persistence of female students, the result from the study has established that financial responsibilities can positively affect the persistence of female students on distance education programs in Ghana. It was therefore recommended that;

$>$ Administrators and managers of distance education institutions should ensure that they restructure modes of paying fees that allow students the chance to pay fees by smaller instalments over the period of their study. This is important due to the fact that most students who have lower earning, have a low tendency of saving large amount of money over a longer period of time.

$>$ The use of mobile money accounts for easy transfer of smaller amounts of money conveniently would be recommendable.

$>$ Female students must be educated on policies of students' loan funds available for access in order to create awareness while distance education institutions and nongovernmental organizations may also establish scholarship schemes to support best female students.

\section{BIODATA and CONTACT ADDRESSES of AUTHORS}

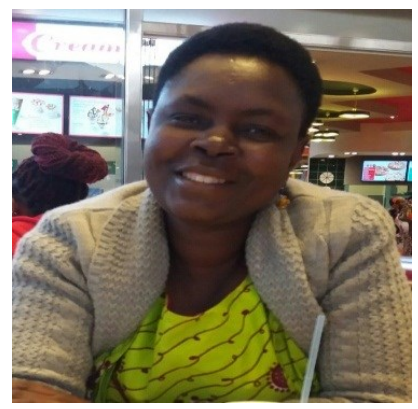

Beatrice Asante SOMUAH graduated from her Ph.D. program at the Department of Educational Management, Policy and Curriculum Studies at Kenyatta University in 2018. She is currently working at College of Distance Education, University of Cape Coast. She is interested in new trends in distance education, teacher education, female studies, leadership and educational management and in new paradigms of scientific research and methods. She is team player and ready to collaborate and share new ideas with other scholars across the globe. 
Beatrice Asante SOMUAH

College of Distance Education, University of Cape Coast,

University Post Office, Cape Coast, Ghana

E-mail: bsomuah@ucc.edu.gh

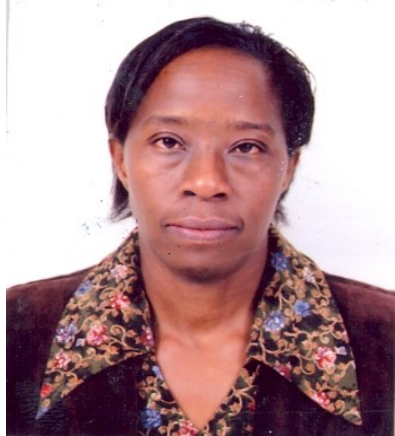

Florence Muthoni ITEGI is a Senior Lecturer at the department of Education Management, Policy and Curriculum Studies at Kenyatta University, Kenya. Dr. Itegi earned PhD in Educational Administration and Planning in 2009. Her research interests are in strategic education management, policy, leadership and behavior modelling. She has over ten papers published in peer reviewed journals, a book on project management, chapter in an international book and made presentations in international conferences. She is a research consultant with wealth of experience in supervision of masters and PhD students' research and enjoys facilitating in seminars and workshops.

Dr. Florence Muthoni. ITEGI

Department of Educational Management Policy and Curriculum Studies

School of Education, Kenyatta University

P. O. Box, 43844-00100, Nairobi Kenya

Phone: + 254723464059

E-mail: muitegi.ku.ac@gmail.com or itegi.florence@ku.ac.ke

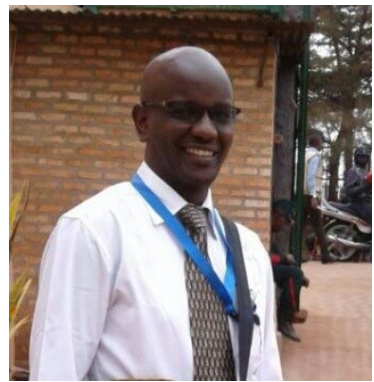

Samson Ikinya KARIUKI is a lecturer and researcher of Educational Curriculum, Research and Evaluation at School of Education, Kenyatta University. Dr. Kariuki gained his Ph.D. in Educational Research and Evaluation in October, 2013. His academic and professional interest is in educational research, monitoring and evaluation, Technical Vocational Education and Training and Curriculum Studies. He has vast knowledge in Research Policy. He has developed TVET Strategies, TVET Policies and Tracer Studies in Kenya, Rwanda and Somaliland.

\section{Samson Ikinya KARIUKI}

Education Management, Policy and Curriculum Studies

School of Education, Kenyatta University

P.O Box 43844-00100, Nairobi, Kenya

Phone: +254 725745166

E-mail: ikinyakariukis@gmail.com

\section{REFERENCES}

Abdu-Raheem, B. O. (2015). Parents ' socio-economic status as predictor of secondary school students' academic performance in Ekiti State, Nigeria. Journal of Education and Practice, 6(1), 123-129. Retrieved from http://www.iiste.org.

Adusah-Karikari, A. (2008). Experiences of women in higher education: A study of women faculty administrators in selected public universities in Ghana. (Unpublished doctoral thesis). Ohio University, Athens, Ohio.

Adu-Yeboah, C. (2011). Constructing higher education experiences through narratives: Selected cases of mature underground women students in Ghana. Phd Thesis, University of Sussex. Retrieved from http://sro.sussex.ac.uk/. 
Al-Dossary, S. A. (2008). A study of the factors affecting student retention at King Saud University, Saudi Arabia: Structural equation modelling and qualitative method. Doctoral dissertation, University of Stirling.

American Association of University Women (2016). For women, student loan debt is an even bigger crisis. Retrieved from http://www.aauw.org/2014/07/08/women-andstudent-loan-debt/.

Bean, J. P. (2005). Nine themes of college student retention. In A. Seidman (Ed.), Student college retention: Formula for student success. New York, NY: Rowman \& Littlefield.

Bean, J. P., \& Metzner, B. S. (1985). A conceptual model of nontraditional undergraduate student attrition. Review of Educational Research, 55(4), 485-540.

Burrus, J., Elliott, D., Brenneman, M., Markle, R., Carney, L., Moore, G., ... Roberts, R. D. (2013). Putting and keeping students on track: Toward a comprehensive model of college persistence and goal attainment. ETS Research Report. Retrieved from https: / / www.mendeley.com.

Bynum, C. S. (2016). The relationship between state financial aid and student persistence and success in college: An examination of Hispanic undocumented immigrant students in Texas Community Colleges. Ph.D Dissertation, Florida State University Libraries.

Carney-Crompton, S., \& Tan, J. (2002). Support systems, psychological functioning, and academic performance of nontraditional female students. Adult Education Quarterly, 52(2), 140- 154.

Creswell, J. W. (2014). Research design: Qualitative, quantitative, and mixed methods approaches. Thousand Oaks: Sage Publications.

Davidson, W. B., Hall, P. B., \& Milligan, M. (2009). The college persistence questionnaire: Development and validation of an instrument that predicts student attrition. Journal of College Student Development, 50(4), 373-390.

http://doi.org/10.1353/csd.0.0079.

Goldrick-Rab, S. (2016). Paying the price: College costs, financial aid, and the betrayal of the American dream. Chicago, IL: University of Chicago Press.

Goldrick-Rab, S. (2010). Challenges and opportunities for improving community college student success. Review of Educational Research, 80(3), 437-469. Retrieved from http://rer.sagepub.com/content/80/3/437.full.

Hill, C. (2016). Pay gap especially harmful for black and Hispanic women struggling with student debt. Retrieved from http://www.aauw.org.

Horn, A. S., \& Reinert, L. (2014). Campus-based practices for promoting student success: Financial aid. Illinois, USA: Midwestern Higher Education Compact.

Jansson, B., Bukuluki, P., Hojer, S. (2017). Higher education in Uganda: Gender, socioeconomic status, geographical background and sponsorship in a group of social work students at Makerere University. International Social Work. https://doi.org/10.1177/0020872817710544.

Kitroeff, N., \& Rodkin, J. (2015). The real payoff from an MBA is different for men and women. Bloomberg Businessweek (October 20, 2015). Retrieved from http://www.bloomberg.com/news/articles/2015-10-20/the-real-cost-of-an-mbais-different-for men-and-women.

Khattak, S. G. (2013). Attitudes of parents towards contemporary female higher education in KPK . Sky Journal of Educational Research Vol. 1(2), 9 -13. 
Mamiseishvili, K., \& Deggs, D. M. (2013). Factors affecting persistence and transfer of lowincome students at public two-year institutions. Journal of College Student Retention: Research, Theory \& Practice, 15(3), 409-432. Retrieved from www.researchgate.net.

McClusky, B. (2017). Investigating the relationships between education and culture for female students in tertiary settings in the UAE. Doctoral thesis, School of Education, Edith Cowan University. Retrieved from http://ro.ecu.edu.au/theses/1974.

Nielsen, K. (2015). "Fake it 'til you make it": Why community college students' aspirations "hold steady". Sociology of Education, 88(4), 265-283. Retrieved from http://soe.sagepub.com.

Nordenmark, M. (2004). Multiple social roles and well-being: A longitudinal test of the role stress theory and the role expansion theory. Acta Sociologica, 47(2), 115-126. http://doi.org/10.1177/0001699304043823.

Nonis, S. A., \& Hudson, G. I. (2006). Academic performance of college students: Influence of time spent studying and working. Journal of Education for Business, 81(3), 151-159. http://doi.org/10.3200/JOEB.81.3.151-159.

Onwuegbuzie, A. J. (2012). Introduction: Putting the mixed back into quantitative and qualitative research in educational research and beyond: Moving towards the radical middle. International Journal of Multiple Research Approaches, 6(3), 192-219. Retrieved from http://www.tandfonline.com.

Paulsen, M. B., \& St. John, E. P. (2002). Social class and college costs: Examining the financial nexus between college choice and persistence. Journal of Higher Education, 73, 189-236.

Reay, D. (2003). A risky business? Mature working-class women students and access to higher education. Gender and Education, 15(3), 301-317. Retrieved from http://www.tandfonline.com.

Renehan, S. (2015). Rising tuition in higher education: Should we be concerned? Visions for the Liberal Arts, 1(1), Article 3. Retrieved from http://scholar.oxy.edu/.

Riel, B. (2011). The cultural context-United Arab Emirates. Eaton Consulting Group. Retrieved from http://www.bobriel.com/pdf\%20files/uae.pdf.

Saleh, A., Yu, Q., Leslie, H. S., \& Seydel, J. (2017). Gender equity, student loans and returns on investment in American higher education. International Journal of Sociology of Education, 6(2), 216-243.

Simpson, 0. (2016). Student support services for success in open and distance learning. Retrieved from www.researchgates.

Terriquez, V., \& Gurantz, O. (2015). Financial challenges in emerging adulthood and students' decisions to stop out of college. Emerging Adulthood, 3(3), 204-214. http://doi.org/10.1177/2167696814550684.

Westrick, P., \& Robbins, S. B. (2012). "Can do" vs. "will do": The relative effects of ACT scores and high school GPA on college performance and retention. Unpublished manuscript. 